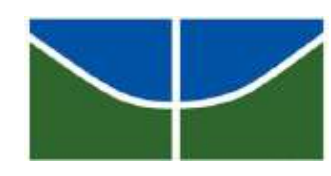

UNIVERSIDADE DE BRASÍLIA

Centro de Excelência em Turismo

Pós-graduação Lato Sensu

Curso de Especialização em Tecnologia de Alimentos

\title{
QUALIDADE MICROBIOLÓGICA DE FRUTAS E HORTALIÇAS MINIMAMENTE PROCESSADAS: UMA REVISÃO
}

\author{
ANA RITA DA COSTA PINTO \\ ORIENTADORA: Professora MSc Lívia de Lacerda de Oliveira Pineli
}




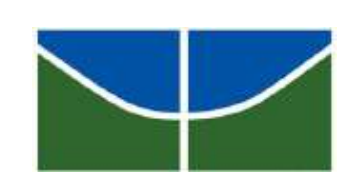

\begin{abstract}
UNIVERSIDADE DE BRASÍLIA
Centro de Excelência em Turismo
\end{abstract}

Pós-graduação Lato Sensu

Curso de Especialização em Tecnologia de Alimentos

\title{
QUALIDADE MICROBIOLÓGICA DE FRUTAS E HORTALIÇAS MINIMAMENTE PROCESSADAS: UMA REVISÃO
}

\begin{abstract}
ANA RITA DA COSTA PINTO
ORIENTADORA: Professora MSc Lívia de Lacerda de Oliveira Pineli

Monografia apresentada ao Centro de Excelência em Turismo - CET, da Universidade de Brasília - UnB, como requisito parcial à obtenção do grau de Especialista em Tecnologia de Alimentos.
\end{abstract}

Brasília - 2007 
Pinto, Ana Rita da Costa.

Qualidade microbiológica de frutas e hortaliças minimamente processadas: uma revisão / Ana Rita da Costa Pinto. - Brasília, 2007. 36. : il.

Monografia (especialização) - Universidade de Brasília, Centro de Excelência em Turismo, 2007.

Orientadora: Lívia de Lacerda de Oliveira Pineli.

1. Qualidade microbiológica. 2. Frutas e hortaliças. 3. Processamento mínimo. I. Título. II. Título : uma revisão. 


\section{UNIVERSIDADE DE BRASÍLIA \\ Centro de Excelência em Turismo \\ Pós-graduação Lato Sensu \\ Curso de Especialização em Tecnologia de Alimentos}

\section{Ana Rita da Costa Pinto}

Aprovado por:

Professora orientadora: MSc Lívia de Lacerda de Oliveira Pineli

Professora: Dra. Karin Eleonora Sávio de Oliveira

Brasília, 15 de Março de 2007. 


\section{DEDICATÓRIA}

À minha família, em especial aos amigos de todas as horas: meu pai, Matias Julio, e minha mãe, Raimunda Costa. 


\section{AGRADECIMENTOS}

A Deus agradeço, sempre. É Ele o meu sustento, Aquele que restaura as forças da minha alma.

A meus pais, Matias Julio Pinto e Raimunda Nonata da Costa Pinto, amigos que souberam me educar para a vida. Obrigada por seu amor, exemplo, paciência e sabedoria.

Um agradecimento especial à professora Lívia Pineli, pelo apoio, paciência e profissionalismo dedicados ao desenvolvimento deste trabalho. Obrigada pela confiança depositada.

Ao Dr. Celso Moretti, da EMBRAPA Hortaliças, pela orientação inicial na busca por artigos relevantes para o desenvolvimento deste trabalho.

Aos amigos de todas as horas, participantes ou não de minha vida acadêmica. A alegria de vocês não me deixou desanimar.

Aos demais professores e professoras do curso, pela grande carga de conhecimento transmitida aos alunos. De alguma forma contribuíram para que eu me tornasse melhor profissionalmente.

Aos colegas e funcionários do curso de Pós-Graduação em Tecnologia de Alimentos, pela troca de experiências e bons momentos vividos.

A todas as pessoas que, de uma forma ou de outra, contribuíram para o êxito de minha vida pessoal e profissional. A estas, o meu sincero carinho. 


\section{EPÍGRAFE}

"O que somos é presente de Deus; no que nos transformamos é o nosso presente a Ele."

São João Bosco 


\section{RESUMO}

O processamento mínimo visa a submeter frutas e hortaliças a um processo industrial que envolve as atividades de seleção e classificação da matéria-prima, pré-lavagem, corte, fatiamento, sanitização, enxágüe, centrifugação e embalagem. $O$ objetivo é obter um produto fresco, saudável e que, na maioria das vezes, não necessite de preparo para ser consumido. A preferência por estes produtos tem aumentado consideravelmente em virtude de diversos fatores, tais como a mudança no perfil da população ao longo dos anos, sua facilidade de preparo ou consumo, a maior participação da mulher no mercado de trabalho, o crescimento do segmento de refeições coletivas e o envelhecimento da população. A conveniência exigida pelo consumidor não tem sido suficiente, no entanto, para a sobrevivência dos minimamente processados no mercado, sendo a manutenção dos atributos de qualidade o fator decisivo para sua compra. Enquanto a maioria das técnicas de processamento de alimentos estabiliza os produtos e retarda sua vida de prateleira, o processamento mínimo aumenta sua perecibilidade, característica que ocorre basicamente em virtude dos danos mecânicos sofridos durante as diferentes etapas envolvidas na obtenção do produto minimamente processado. Considerando-se os perigos potenciais que tornam a qualidade microbiológica e a segurança de frutas e vegetais minimamente processados assunto de alta prioridade, foi desenvolvida uma revisão de literatura sobre qualidade destes produtos, indicando-se as etapas críticas na redução da contaminação dentro do fluxograma de processamento mínimo, juntamente com trabalhos consultados cujo tema era pautado na interferência de determinados tratamentos na qualidade microbiológica destes alimentos. Concluiu-se sobre a importância dos diversos tratamentos utilizados, especialmente de forma combinada, como forma de reduzir a contaminação microbiana dos minimamente processados e contribuir para a comercialização de produtos de qualidade confiável e com vida útil prolongada.

Palavras-chave: processamento mínimo, frutas e hortaliças, qualidade, etapas críticas, tratamentos. 


\begin{abstract}
The minimal processing aims to submit fruits and vegetables to a industrial processing that involves the activities of selection e classification of the raw material, cleaning, cutting, peeling, sanitation, centrifugation and packing. The mean point is to get a fresh product, healthy and that, most of time, do not needs any preparation to be consumed. The preference for these products has been incresead considerably due to many factors, such as changing in profile of the population through the years, the facility of preparing or consuption, a major participation of women in the marketplace, the increasing of the segment of self-service restaurants and the maturing of population. The convenience required by the consumer has not been enough, howerver, to the surviving of fresh-cut in the market, being the maintenance of the attributes of quality the decisive factor for its purchase. While most of technics of food processing stablish the products and delay its shelf-life, the minimal processing increases its perishabilty, caracteristic that occurs basically due mecanical injury suffered during the different steps envolved in obtention of the fresh-cut product. Considering the potential hazard that turn down microbial quality and fruits and vegetables safety higy priority matter, there has been proceeded a literature review, indicating the critical steps in reducing the contamination of product inside the processing flowchart, together with works wich topic was lined in the interference of determined treatments in microbial quality of these products. The conclusion was the importance of varied treatments used, specially in combined ways, as a method to reduce the microbial contamination of fresh-cut products and to contribute to the marketing of credible quality and prolonged shelf-life products.
\end{abstract}

Key-words: minimal processing, fruits and vegetables, quality, critical steps, treatments. 


\section{LISTA DE ILUSTRAÇÕES}

Ilustração 1 - Fluxograma geral do processamento mínimo...........................11 


\section{LISTA DE TABELAS}

Tabela 1 - Resultados da pesquisa referente à qualidade microbiológica de frutas e

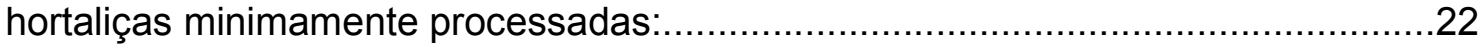

Tabela 2 - Principais microorganismos patogênicos encontrados em frutas e

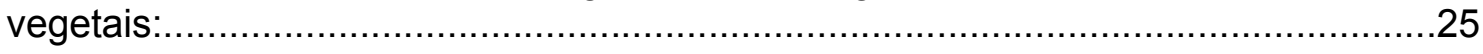

Tabela 3 - Microorganismos mais comuns em hortaliças e frutas:........................26 


\section{LISTA DE ABREVIATURAS E SIGLAS}

AC: Atmosfera controlada

AM: Atmosfera modificada

${ }^{\circ} \mathrm{C}$ : Graus Celsius

$\mathrm{Cl}_{2}$ : Gás Cloro

$\mathrm{CHCl}_{3}$ : Clorofórmio

$\mathrm{CH}_{3} \mathrm{CO}_{3} \mathrm{H}$ : Ácido Peroxiacético

$\mathrm{CO}_{2}$ : Gás Carbônico

FDA: Food and Drugs Administration

g: Grama

IFPA: International Fresh-Cut Produce Association

KGy: Kilogray

KOH: Hidróxido de Potássio

I: Litro

mg: Miligrama

MP: Minimamente processado

$\mathrm{NaH}_{2} \mathrm{PO}_{2}$ : Hipofosfito de Sódio

NaOH: Hidróxido de Sódio

$\mathrm{Na}_{2} \mathrm{SO}_{3}$ : Sulfito de sódio

$\mathrm{O}_{2}$ : Gás Oxigênio

$\mathrm{O}_{3}$ : Gás Ozônio

PET: Polietileno Tereftalato

pH: Potencial Hidrogeniônico

U.F.C.: Unidade Formadora de Colônia 


\section{SUMÁRIO}

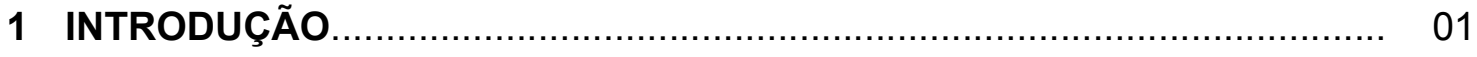

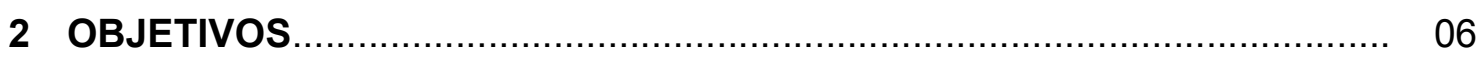

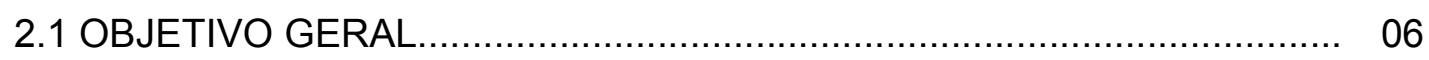

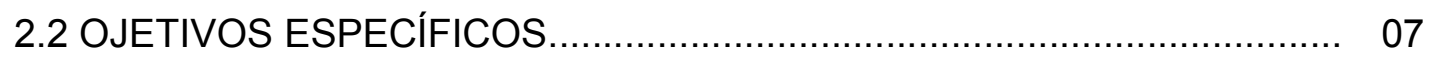

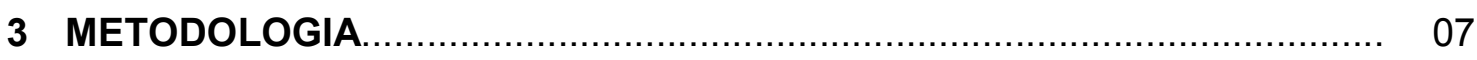

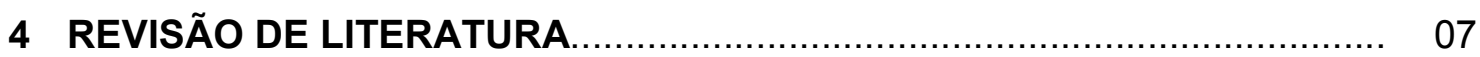

4.1 Qualidade de produtos minimamente processados................................ 07

4.2 Fatores que influenciam a qualidade de produtos minimamente

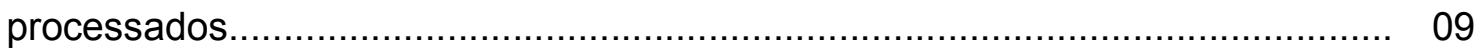

4.3 Etapas críticas do processamento mínimo......................................... 10

4.4 Aspectos microbiológicos de frutas e hortaliças minimamente

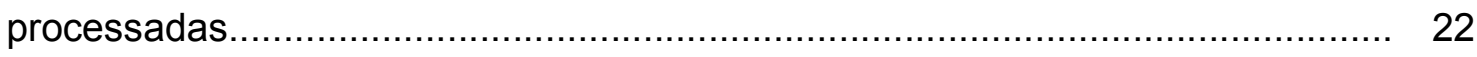

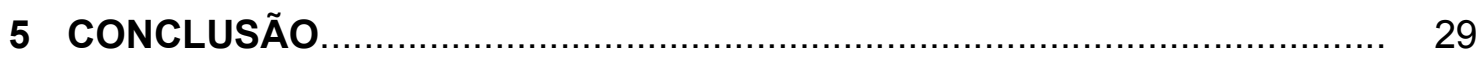

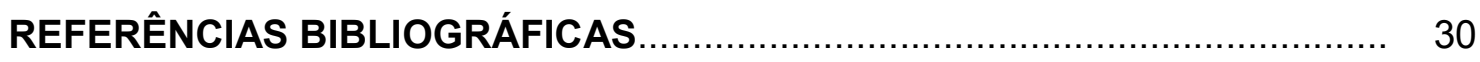




\section{INTRODUÇÃO}

O processamento mínimo visa submeter frutas e hortaliças a um processo industrial que envolve as atividades de seleção e classificação da matéria-prima, pré-lavagem, corte, fatiamento, sanitização, enxágüe, centrifugação e embalagem, visando a obtenção de um produto fresco, saudável e que, na maioria das vezes, não necessita de preparo para ser consumido (IFPA, 1999; MORETTI, 2003a).

Outro ponto relevante é a mudança no perfil da população ao longo dos anos. O setor agroalimentar, atento a essa mudança de comportamento, vem diferenciando-se de várias maneiras, procurando ofertar produtos e serviços com o desafio de satisfazer as necessidades da população, tanto em termos nutricionais como gastronômicos, sem esquecer a praticidade e a qualidade necessárias (SOUZA et al., 1998).

Apesar da disponibilidade de produtos agrícolas no Brasil, as perdas ainda são significativas em virtude do uso de tecnologias inadequadas durante o seu cultivo, manuseio, armazenamento e conservação. Uma alternativa para minimizar tais perdas é o processamento mínimo de frutas e vegetais (CHITARRA, 1999). É, desta forma, uma tecnologia que atende aos interesses de consumidores e de produtores (PEREIRA, et al., 2004), gerando, para estes, uma renda adicional e contribuindo, em conseqüência, para um importante e positivo impacto econômico e social (MORETTI, 2003a).

Outra justificativa para a demanda por produtos minimamente processados MP - é a facilidade de preparo ou consumo, atributos que, aliados à elevada qualidade, são cada vez mais valorizados pelos consumidores (AGUILA et al., 2006). Em pesquisa do Ministério da Integração Nacional, realizada entre 1999 e 2000, observou-se que $66,3 \%$ dos consumidores entrevistados nos Estados de São Paulo, Minas Gerais e Rio de Janeiro optaram por hortícolas minimamente processadas por sua praticidade (SOUZA, 2001). Moretti (2001) também associa o crescente interesse pelos minimamente processados à maior participação da mulher no 
mercado de trabalho, ao crescimento do segmento de refeições coletivas e ao envelhecimento da população.

Segundo Souza (2001), a população com mais de 40 anos tende a ser mais exigente, valorizando mais suas compras e tendo maior preocupação com qualidade e alimentos mais saudáveis. A diminuição do tempo disponível para o preparo de refeições em casa também interfere na procura por produtos minimamente processados, e é decorrente do aumento da participação feminina no mercado de trabalho (SOUZA et al., 1998).

A preferência por tais produtos também está relacionada à diminuição no tamanho das famílias, ao aumento do número de pessoas que moram sozinhas e a uma maior preocupação com a saúde. Popkin (2001) chamou de transição nutricional a série de mudanças no padrão alimentar dos indivíduos, associadas a mudanças de caráter econômico, social e demográfico, que repercutem na saúde da população, sendo tal conceito outro fator que determina a preferência por produtos mais frescos e prontos para o consumo (SILVA et al., 2002 apud PINELI e ARAÚJO, 2006).

Uma série de fatores sociais justifica a evolução rápida destes produtos em todo o território nacional, especialmente nas grandes concentrações urbanas (NASCIMENTO, 2001; SAABOR, 2001). Somente no Estado de São Paulo, pesquisas realizadas pelo Ministério de Integração Nacional indicam uma preferência de $32 \%$ dos consumidores por produtos minimamente processados (SOUZA, 2001).

De acordo com a Associação Brasileira das Empresas de Refeições Coletivas - ABERC, a partir dos números gerados pelo segmento no ano 2005, o mercado de refeições coletivas fornece 6,5 milhões de refeições/dia, movimenta uma cifra de 6,9 bilhões de reais por ano, oferece 175 mil empregos diretos, consome diariamente 3,0 mil toneladas de alimentos e representa para os governos uma receita de 1 bilhão de reais anuais entre impostos e contribuições (ABERC, 2006). Neste mercado, existe uma demanda para produtos de processamento mínimo (SOUZA, 2001), com grande interesse por parte de empresas de alimentação rápida, hotéis, 
restaurantes de comida a quilo e empresas de refeições para aeroportos e portos (“catering" aéreo e marítimo) (MORETTI, 1999).

A conveniência exigida pelo consumidor não é suficiente, no entanto, para a sobrevivência dos MP no mercado, sendo a manutenção dos atributos de qualidade o fator decisivo (SKURA e POWRIE, 1995). Para corroborar essa idéia, Souza (2001), com base em pesquisa realizada em 1998, relata que os itens frescor, refrigeração inadequada, bactérias/germes e contaminação totalizam $55,6 \%$ da preocupação e podem afetar diretamente a qualidade dos produtos minimamente processados, indicando que $\mathrm{o}$ aspecto qualidade realmente interessa ao consumidor. Tal relato indica que a preocupação com a qualidade deixou de ser uma simples exigência burocrática dos órgãos de regulamentação e inspeção, passando a ser uma estratégia fundamental e indispensável para garantir a competitividade (MORETTI, 2003b).

Segundo Durigan e Sargent (1999), hortaliças frescas preparadas já são populares no mercado brasileiro. O contrário não ocorre com as frutas prontas para consumo, em virtude da falta de conhecimento com relação ao seu comportamento fisiológico após o processamento. Tal complicação aumenta com as propriedades naturais de frutas que completam seu processo de maturação no pós-colheita (CANTWELL, 2000). Segunda a autora, encontrar o equilíbrio ideal entre qualidade no sabor e a firmeza deste alimento é o principal ponto a ser destacado sobre a vida de prateleira das frutas minimamente processadas. Desta forma, definir as melhores condições de armazenamento e procedimentos no manuseio de frutas destinadas ao processamento mínimo torna-se um grande desafio.

Dentre os fatores que influenciam a qualidade das frutas pré-cortadas, encontram-se as condições de crescimento da cultivar utilizada, as práticas culturais, o tipo de cultivar adotada, o ponto e os métodos de colheita, o manuseio, os padrões de inspeção e a duração e as condições de armazenamento destes produtos (ALVES et al., 2000).

Do ponto de vista microbiológico, existem alguns aspectos específicos para os minimamente processados: são em geral consumidos sem etapas críticas de 
eliminação de patógenos; podem ocorrer temperaturas abusivas durante sua distribuição e exposição; alguns microorganismos podem desenvolver-se mesmo em baixas temperaturas e atmosferas modificadas. São perigos potenciais que tornam a qualidade microbiológica e a segurança de frutas e vegetais minimamente processados assuntos de alta prioridade (CANTWELL, 2000).

Outra pesquisa realizada em 1998 pelo Ministério da Integração Nacional, cujo objetivo foi entender a demanda e identificar os consumidores dos hortifruti préprocessados, comparando-os com produtos a granel, indicou que os preços destes produtos em supermercados são, em média, cerca de $180 \%$ superiores aos das mesmas frutas e hortaliças vendidas a granel, chegando a alcançar valores de até $400 \%$, o que pode ser considerado um fator limitante no aumento do consumo dos pré-processados (SAABOR, 1999). Nesta mesma pesquisa, realizada com consumidores do Estado de São Paulo, as principais razões para o consumidor não comprar pré-processados são a qualidade (da qual desconfiam) e o preço.

Enquanto a maioria das técnicas de processamento de alimentos estabiliza os produtos e prorroga sua vida de prateleira, o processamento mínimo aumenta sua perecibilidade (CANTWELL, 2000; MORETTI et al., 2003; SCHLIMME, 1995). Tal característica ocorre basicamente em virtude dos danos mecânicos sofridos durante as diferentes etapas envolvidas na obtenção do produto minimamente processado (MORETTI et al., 2003; BURNS, 1995).

O corte nos tecidos leva à perda da integridade celular e conseqüente dano à compartimentalização de enzimas e substratos, contribuindo para reações de escurecimento e formação de metabólitos secundários envolvidos na produção de odores desagradáveis (BURNS, 1995). Este é um comportamento típico observado em tecidos de plantas que foram danificadas ou expostas a condições de estresse, implicando aumento na respiração (CANTWELL, 2000) e produção de etileno (BURNS, 1995; BRECHT, 1995) e, em alguns casos, induzindo processos de cicatrização (BRECHT, 1995). Também o exsudato presente na superfície do corte torna-se um meio ótimo para crescimento de fungos e bactérias (BURNS, 1995; CANTWELL, 2000), cuja disseminação é ainda mais facilitada com a remoção da casca destes produtos (VANETTI, 2000; CANTWELL, 2000). 
Outras conseqüências da injúria são reações de oxidação lipídica, indução na síntese de etileno, degradação da membrana lipídica (BRECHT, 1995) e aumento elevado na perda de água (VITTI et al.; 2003). Há ainda outro ponto bastante relevante, a perda na qualidade nutricional (conteúdo de açúcares, ácidos e vitaminas), resultante das reações bioquímicas desencadeadas com o dano mecânico (CANTWELL, 2000), e alterações no sabor, aroma (MORETTI e SARGENT, 2000) e textura do produto (CANTWELL, 2000), reduzindo de maneira potencial a sua aceitação.

De acordo com Moretti e colaboradores (2003), o controle de temperatura é a melhor forma de prevenir as alterações causadas por injúria mecânica. Outra ferramenta de controle das taxas de respiração e da deterioração é a adoção da atmosfera modificada, a qual, em sinergia com baixas temperaturas, é capaz de ampliar o tempo de vida útil dos minimamente processados. Atmosferas controladas reduzem as taxas de respiração e produção do hormônio etileno (MORETTI et al., 2003), além de evitar o amaciamento dos tecidos destes produtos, em especial das frutas (CANTWELL, 2000).

Nessas circunstâncias, justifica-se o alto custo destes alimentos no mercado, que demandam materiais de alta qualidade para manutenção de sua vida de prateleira e uma estrita sanitização. O preparo e o manuseio dos minimamente processados, desta forma, requerem uma profunda integração entre as tecnologias de produção, pós-colheita e ciência de alimentos, juntamente com um marketing especializado (CANTWELL, 2000). O preço elevado dos minimamente processados afeta, dentre outros, o setor de alimentação coletiva, cuja demanda por estes produtos é alta e crescente (SOUZA, 2001).

O marketing de produtos minimamente processados, por sua vez, tem como principal aliado a manutenção de um nível elevado de qualidade sensorial para uma duração adequada no pós-colheita. Outros fatores vitais para um marketing bemsucedido são: controle de qualidade para tratamentos pós-colheita; embalagem adequada, com uso de gráficos e propaganda informativa; e preço competitivo, dentre outros (SCHLIMME, 1995). Ainda, segundo o autor, a chave, no futuro, para o 
sucesso do marketing será a oferta constante de produtos de alta qualidade de maneira uniforme.

O setor de minimamente processados encontra diversos desafios conjunturais, dentre os quais pode-se citar a manutenção da cadeia do frio, a segurança alimentar, o desenvolvimento de cultivares mais adaptadas ao processamento, a disponibilidade de equipamentos fabricados no país, embalagens a preços competitivos e com permeabilidade adequada, e a elaboração de uma legislação específica para estes produtos (MORETTI, 2001; MORETTI, 1999). Também se faz necessário o desenvolvimento de soluções sanitizantes e técnicas que permitam prolongar a vida de prateleira destes alimentos (MORETTI, 1999), retardando, assim, as alterações fisiológicas indesejáveis que representam um dos problemas mais cruciais no processamento mínimo (BURNS, 1995).

São muitas as dificuldades e os desafios vividos pela indústria de minimamente processados, especialmente no que diz respeito à qualidade destes produtos, visando à segurança alimentar do consumidor e ao aumento de sua vida de prateleira. Assim, faz-se necessária a realização de extensivos trabalhos de pesquisa, com o objetivo de desenvolver novas tecnologias ou mesmo revisar o tema, contribuindo para a difusão de informações sobre o assunto.

\section{OBJETIVOS}

\subsection{OBJETIVO GERAL}

O objetivo geral deste trabalho é revisar os principais aspectos relacionados à qualidade microbiológica de frutas e hortaliças minimamente processadas. 


\subsection{OBJETIVOS ESPECÍFICOS}

Os objetivos específicos foram sumarizar dados relacionados à qualidade higiênico-sanitária de frutas e hortaliças minimamente processadas e catalogar as informações coletadas em tabela-resumo.

\section{METODOLOGIA}

O trabalho consistiu de uma pesquisa exploratória de caráter qualitativo, com a utilização de livros de referência na área de tecnologia, fisiologia e microbiologia de frutas e vegetais, além de artigos científicos relacionados ao processamento mínimo, presentes em publicações periódicas impressas ou indexadas do período de 1998 a 2006. Trabalhos clássicos sobre o assunto, publicados anteriormente a este período e sempre citados nas publicações mais recentes, também foram consultados. O foco principal foram artigos sobre qualidade higiênico-sanitária, cujos dados serviram para corroborar as informações teóricas presentes na literatura consultada. Os artigos eletrônicos foram consultados nas bases de dados da Scientific Electronic Library Online - SciELO e da Embrapa Hortaliças, nas línguas inglesa e portuguesa.

As palavras-chave utilizadas na pesquisa eletrônica foram: processamento mínimo, frutas e hortaliças e qualidade microbiológica.

\section{REVISÃO DE LITERATURA}

\subsection{QUALIDADE DE PRODUTOS MINIMAMENTE PROCESSADOS}

A definição de qualidade em produtos minimamente processados inclui os atributos de aparência, tamanho, cor e, como afirmam Souza et al. (1998), também sabor, textura, controle no uso de agrotóxicos, embalagem e controle sanitário. 
A qualidade de produtos minimamente processados tem íntima relação com a manutenção das suas características organolépticas e com o controle da microbiota contaminante (MORETTI, 2003a).

O aumento da demanda por produtos minimamente processados traz grandes desafios no que diz respeito ao desenvolvimento das tecnologias de armazenamento. Estes produtos apresentam uma vida-de-prateleira extremamente curta se comparada ao produto inteiro, já que, com o corte, os tecidos internos do vegetal são expostos e o metabolismo celular torna-se acelerado (KLUGE et al., 2003; VITTI, et al., 2003; BURNS, 1995). Shewfelt (1986) reforça que a extensão da vida de prateleira é o principal objetivo das pesquisas relacionadas ao pós-colheita de frutas e vegetais.

Entende-se como vida de prateleira o período de tempo no qual espera-se que um produto mantenha um nível pré-determinado de qualidade sob condições de armazenamento específicas (SHEWFELT, 1986). Devido a sua alta perecibilidade, a vida de prateleira dos produtos minimamente processados tem sido, geralmente, de até 5 dias. De acordo com Vitti (2003), aumentar a vida de prateleira desses produtos para 10 dias traria grandes benefícios para o mercado, reduzindo perdas e possibilitando maior expansão e flexibilidade de comercialização. A maior dificuldade, segundo a autora, está no desenvolvimento de tecnologias de armazenamento que permitam aumentar a conservação dos produtos minimamente processados sem, no entanto, afetar sua qualidade.

Os hipermercados e grandes lojas chegam a perder entre $4 \%$ e $8 \%$ com a perecibilidade de hortigranjeiros. É um ponto importante, por significar custo para o supermercado e estar muito ligado à questão da embalagem e manuseio do produto. Tais aspectos podem ser trabalhados pelo produtor, tanto em nível de propriedade quando em nível da sua distribuição no supermercado (SOUZA et al., 1998). 


\subsection{FATORES QUE INFLUENCIAM A QUALIDADE DE PRODUTOS MINIMAMENTE PROCESSADOS}

As frutas e hortaliças são hospedeiras de uma microflora bastante diversificada, que normalmente não inclui os tipos patogênicos ao homem. Em geral, estes produtos, quando intactos, são seguros para o consumo, pois sua casca superficial constitui uma barreira física e química eficaz contra a maioria dos microorganismos. Além disso, caso haja danos à casca, a acidez da polpa previne o crescimento microbiano. Nos vegetais, a microflora predominante é composta por organismos do solo. A flora deteriorante usual, que inclui bactérias do gênero Erwinia e Pseudomonas, normalmente possui vantagem competitiva sobre outros organismos que potencialmente poderiam ser prejudiciais aos seres humanos (CANTWELL, 2002).

A fisiologia de frutas e vegetais minimamente processados é essencialmente a de um tecido que sofreu injúria ou foi exposto a condições de estresse. Tal situação reflete no aumento da taxa de respiração e na produção de etileno, além de reações de escurecimento oxidativo, oxidação lipídica e perda de água (BRECHT, 1995). Além disso, o exsudato resultante do corte é um meio favorável para o crescimento fúngico e bacteriano. Estas alterações fisiológicas indesejáveis são alguns dos problemas mais cruciais no processamento mínimo (BURNS, 1995) e, aliadas à manipulação do produto durante $\mathrm{O}$ processamento, aumentam a possibilidade de contaminação com organismos patogênicos (AGUILA et al., 2006).

O crescimento microbiano nos produtos minimamente processados é controlado, principalmente, com sanitização adequada e temperaturas devidamente controladas ao longo de toda a cadeia produtiva. A sanitização dos equipamentos $e$ o uso de água tratada com cloro consistem em procedimentos padrão. A temperatura baixa durante e após o processamento geralmente retarda 0 crescimento microbiano, mas pode selecionar o meio para o crescimento de organismos psicrotróficos, como Pseudomonas. Além disso, o excesso de umidade aumenta o crescimento microbiano, tornando a remoção da água de lavagem e de sanitização pela centrifugação um ponto crítico do processo (CANTWELL, 2002). 
Outra maneira de assegurar a qualidade desses produtos é a adoção da atmosfera modificada (PILON et al., 2006; FANTUZZI et al., 2004) e a utilização de adequada permeabilidade do filme de embalagem (FANTUZZI et al., 2004), que é capaz de modificar a umidade e a composição atmosférica ao redor dos produtos processados, mudando seu perfil microbiológico (CANTWELL, 2002).

É complexa a gama de fatores relacionados à qualidade dos minimamente processados; desta forma, estes serão abordados, com mais profundidade, nos próximos capítulos, iniciando-se, primeiramente, com as etapas mais críticas na redução da contaminação destes produtos durante seu processamento.

\subsection{ETAPAS CRÍTICAS DO PROCESSAMENTO MÍNIMO}

Uma matéria-prima de excelente qualidade é essencial para a qualidade do produto final do processamento mínimo (MORETTI \& PUSHMANN, 2006). Para esses autores, cuidados devem ser tomados ainda durante o cultivo, conduzindo a cultura com atenção especial à nutrição mineral, ao controle fitossanitário e ao manejo de água e solo, dentre outros.

Um dos períodos críticos para a obtenção de matéria-prima de qualidade é a colheita, que requer cuidados adicionais no manuseio de hortaliças com maior susceptibilidade a injúrias de impacto e abrasões (MORETTI \& PUSHMANN, 2006; LIMA et al., 2006).

Ainda no campo, outra atenção especial deve ser dada ao aspecto higiênico, que inclui desde a limpeza adequada de utensílios e equipamentos utilizados na colheita e manuseio da matéria-prima, até a remoção e destruição de materiais infectados que podem inocular doenças nos sadios (LIMA et al., 2006).

Assim sendo, pode-se resumir as operações no campo, relacionadas com a qualidade do produto, aos seguintes pontos (LIMA et al., 2006):

- Inspeção da matéria-prima (defeitos, maturação, contaminação visual);

- Seleção para retirada de produtos fora de especificação;

- Pré-resfriamento para retirada do calor de campo. 
Partindo das etapas citadas, segue-se para o processamento mínimo, cujo fluxograma geral (Figura 1) e descrição das principais etapas encontram-se a seguir:

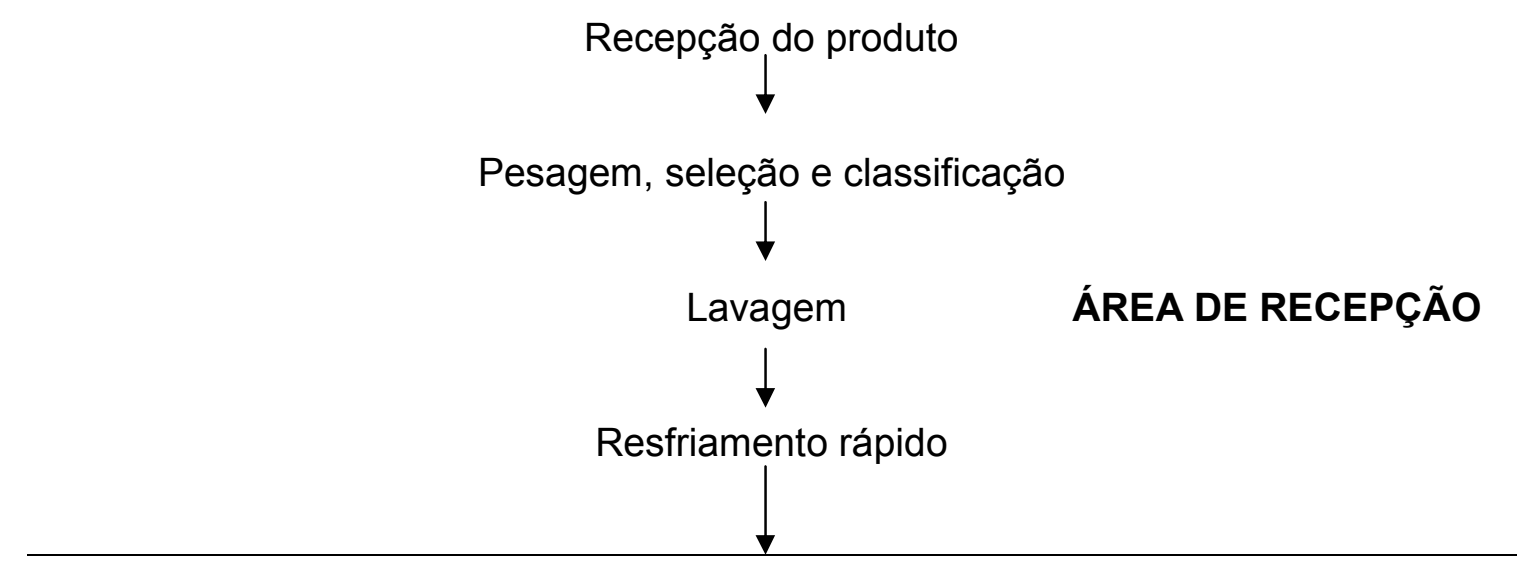

Corte, descasque, fatiamento, torneamento

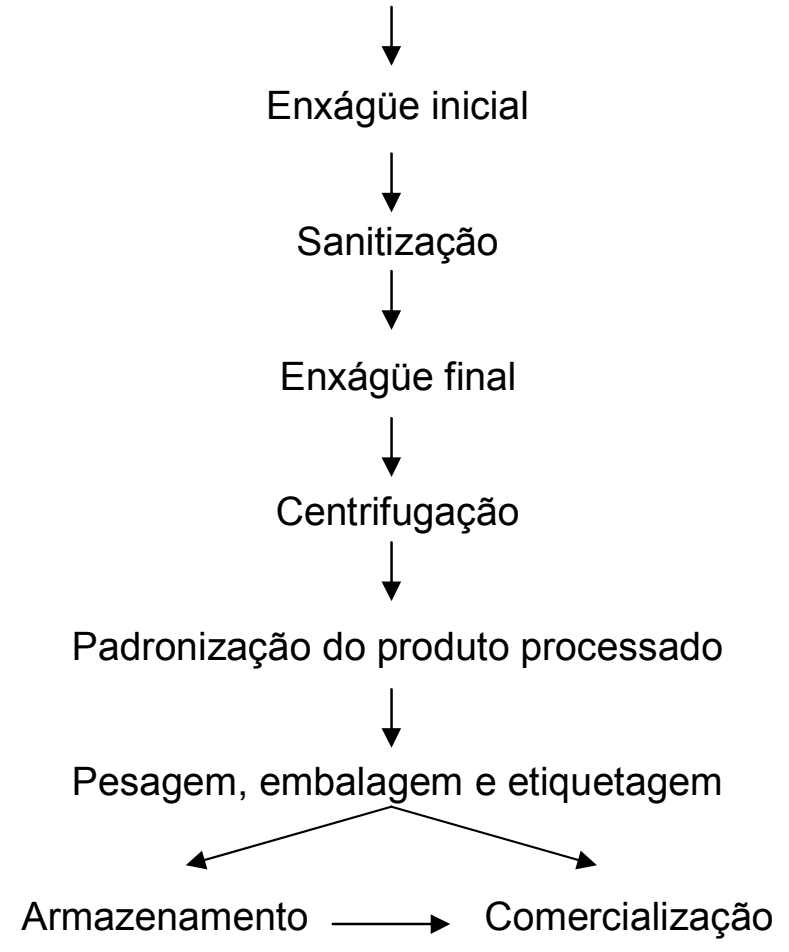

Figura 1: Fluxograma geral do processamento mínimo

Seleção: Nesta etapa, removem-se eventuais materiais indesejáveis, danificados, fora de padrão ou com sinais de podridão. Em seguida, faz-se a classificação por aparência e tamanho, a fim de padronizar a matéria-prima para o tipo de processamento a que se destina (PINELI, 2005; MORETTI e PUSCHMANN, 2006). 
Segundo Mattiuz (2004), é necessária a realização desta etapa por pessoas treinadas adequadamente.

Lavagem: Consiste em lavar a matéria-prima em água limpa e de boa qualidade, a fim de remover a matéria orgânica e as impurezas provenientes do campo que, porventura, ficarem aderidas à superfície (KLUGE \& VITTI, 2004; MORETTI e PUSCHMANN, 2006).

Corte, descasque, fatiamento, torneamento: São etapas do processamento mínimo que dependem das características do material a ser utilizado (MORETTI e PUSCHMANN, 2006). O descascamento e o corte podem ser manuais ou mecânicos, com auxílio de peelers, discos abrasivos para retirada da película externa do produto (VITTI et al., 2004). Também podem ser realizados por lixívia (uso de soluções alcalinas de $\mathrm{NaOH}$ ou $\mathrm{KOH}$ ), vapor sob alta pressão ou água em ebulição (LIMA et al., 2006).

É um momento crucial dentro do processo, visto que os danos sofridos pelos vegetais levam à liberação de sumo rico em nutrientes (HURST, 1995) e a um aumento da respiração dos tecidos (LIMA et al., 2006), o que permite um desenvolvimento microbiano mais rápido e maiores populações de microorganismos tanto no produto quanto no equipamento utilizado no processo (HURST, 1995). Além disso, estas operações têm o potencial de recontaminar o produto (JAY, 2005), em virtude da alta manipulação a que são submetidos (CANTWELL, 2000).

Enxágüe inicial: Consiste na imersão rápida do produto processado em água a $5^{\circ}$ C, com a finalidade de remover o suco celular extravasado, por rompimento das membranas celulares, no corte. Esta é uma maneira de inibir o crescimento de microorganismos - citado anteriormente - e evitar que a matéria orgânica liberada reaja com o cloro livre da solução sanitizante - próxima etapa -, formando compostos indesejáveis e reduzindo a eficiência da sanitização (MORETTI e PUSCHMANN, 2006).

A lavagem dos minimamente processados é a prática mais comum para se obter um produto mais seguro microbiologicamente. É fundamental, no entanto, que 
a água utilizada seja de boa qualidade, requisito que, não cumprido, torna a água fonte de contaminação primária dentro da planta de processamento (BERBARI et al., 2001; ZAGORY, 2000). De acordo com BERBARI e colaboradores (2001), a eficácia da lavagem é aumentada com a inclusão de antimicrobianos ou desinfetantes nesta água. O cloro, por exemplo, mantém uma baixa carga microbiana na água, impedindo que esta se torne um reservatório de bactérias para contaminação do produto (ZAGORY, 2000).

Sanitização: De acordo com Moretti e Puschmann (2006), esta etapa acontece com a imersão do produto cortado em solução com $150 \mathrm{mg} / \mathrm{L}$ a $200 \mathrm{mg} / \mathrm{L}$ de cloro livre, próximo a $5^{\circ} \mathrm{C}$, por um período de 10 minutos.

Desinfetante com propriedades oxidantes fortes, o cloro é solúvel em água, seja pela injeção de gás $\left(\mathrm{Cl}_{2}\right)$, seja pela adição de sais de hipoclorito. A solução pronta, denominada água clorada, consiste da mistura de gás, ácido hipocloroso e íons de hipoclorito, em quantidades que variam com o pH aquoso (SUSLOW, 1997), este último de grande importância para sua eficiência (MORETTI e PUSCHMANN, 2006).

Cloro "livre", "ativo" ou "disponível" são termos que descrevem a quantidade de cloro em qualquer forma disponível para reações oxidativas e de desinfecção (SUSLOW, 1997). Ainda segundo Suslow (1997), vale lembrar que os termos citados não incluem o cloro combinado com amônia ou outras formas menos disponíveis de cloro com fraca atividade antimicrobiana, como as cloraminas.

Os compostos à base de cloro são germicidas de amplo espectro de ação. Reagem com as proteínas da membrana de células microbianas, interferindo, desta forma, no transporte de nutrientes, e promovendo o extravasamento dos componentes celulares (VANETTI, 2000).

A concentração máxima de ácido hipocloroso é atingida em $\mathrm{pH} 6,0$. No entanto, a melhor combinação de atividade e estabilidade é alcançada mantendo-se o pH da água entre 6,5 e 7,5. Em um pH baixo, o gás cloreto é liberado da água (SUSLOW, 1997). 
De acordo com Suslow (1997), o cloro pode oxidar materiais orgânicos de forma incompleta, produzindo subprodutos indesejáveis na água de processamento, tais como o clorofórmio $\left(\mathrm{CHCl}_{3}\right)$ ou outros trihalometanos, suspeitos de serem potenciais carcinogênicos. $\mathrm{Em} \mathrm{pH}$ alto, o cloro reage com bases nitrogenadas para produzir cloraminas. Além do $\mathrm{pH}$, fatores como temperatura, matéria orgânica e concentração do sanitizante, sozinhos ou combinados, irão determinar a ação antimicrobiana da solução sanitizante à base de cloro (VANETTI, 2000).

O teor de cloro livre na água pode ser reduzido pela alta reatividade do cloro com matéria orgânica na presença de oxigênio. Essa é a razão pela qual a troca da solução sanitizante é recomendada após 2 a 3 usos ou quando o nível de cloro livre for menor que $100 \mathrm{mg} / \mathrm{L}$ (MORETTI e PUSCHMANN, 2006).

O cloro é o sanitizante mais utilizado em alimentos (VANETTI, 2000). É eficiente, de baixo custo e tem larga aplicação; por exemplo, na forma de spray (BERBARI et al., 2001). Existem, porém, outros tipos de sanitizantes, tais como o dióxido de cloro, o ozônio, o ácido peroxiacético, o hipofosfito de sódio, o sulfito de sódio e a iluminação ultravioleta (SUSLOW, 1997).

O dióxido de cloro tem potencial oxidante 2,5 vezes maior que o do gás de cloro, porém torna-se explosivo em concentrações acima de $10 \%$ ou em temperaturas acima de $130^{\circ} \mathrm{C}$. A necessidade de programas de segurança especializados e a adoção de sistemas fechados para evitar o enfraquecimento da solução concentrada e a evaporação, pela característica volátil, são alguns dos fatores que tornam o dióxido de cloro relativamente caro para aplicação em áreas de produção (SUSLOW, 1997).

Conforme Suslow (1997), o ozônio $\left(\mathrm{O}_{3}\right)$ é outro forte agente oxidante usado no processo de desinfecção. No entanto, concentrações seguras e efetivas ainda são difíceis de se manter na água do processo, considerando que os sistemas automáticos de detecção de concentração ideal para segurança humana ainda não são confiáveis. Além disso, o ozônio é altamente instável em água e se decompõe a oxigênio em um curto espaço de tempo (ZAGORY, 2000). Em água com partículas 
suspensas e substâncias orgânicas, a meia-vida do ozônio pode ser menor que 1 minuto (SUSLOW, 1997).

Líquido incolor e com odor pungente, o ácido peroxiacético $\left(\mathrm{CH}_{3} \mathrm{CO}_{3} \mathrm{H}\right)$ também é usado no tratamento de superfícies de frutas e vegetais. Após sua aplicação, recomenda-se a lavagem do produto processado com água potável (SUSLOW, 1997). É um produto que se mantém ativo mesmo em mudanças de $\mathrm{pH}$ e é menos sensível no contato com a matéria orgânica (ZAGORY, 2000).

Apesar do hipofosfito de sódio $\left(\mathrm{NaH}_{2} \mathrm{PO}_{2}\right)$ ser considerado ativo contra formação de esporos microbianos, resistentes aos níveis padrão de cloro, seu desempenho em água é bastante fraco. Tem-se ainda o sulfito de sódio $\left(\mathrm{Na}_{2} \mathrm{SO}_{3}\right)$, considerado um desinfetante, porém com uso proibido em qualquer concentração pela Food and Drugs Administration - FDA (SUSLOW, 1997), órgão americano responsável pela regulação de alimentos, drogas, medicamentos, e outros assuntos relacionados à saúde pública.

Uma alternativa ao uso de substâncias químicas na água utilizada no processamento mínimo é a iluminação ultravioleta. De acordo com Zagory (2000), trata-se de um método que possui ação germicida, não deixa resíduos químicos e não é afetado pelas características químicas da água. No entanto, só é ativo superficialmente e, por isso, seu efeito depende da manutenção de um fornecimento de água limpa por meio da filtração (SUSLOW, 1997).

A irradiação é outra alternativa que visa preencher o quesito 'inocuidade' nos alimentos minimamente processados. É uma tecnologia que mantém as características de frescor dos vegetais e é economicamente viável para a redução de perdas pós-colheita. Aumenta a vida útil e melhora a qualidade higiênica dos alimentos pelo fato de reduzir a população de microorganismos e inativar parasitas (LANDGRAF e NUNES, 2006). As autoras explicam, no entanto, que esse processo pode ser limitado em alguns alimentos, por produzir efeitos indesejáveis nas qualidades sensoriais em virtude das doses exigidas para atingir a inativação microbiana. Isto significa que cada produto requer uma dose mínima de radiação 
suficiente para reduzir o crescimento bacteriano, o que, no entanto, nem sempre traz efeitos benéficos sob o aspecto organoléptico do alimento.

Em estudo realizado com manga minimamente processada, Vieites e colaboradores (2005) avaliaram o efeito sanitizante da radiação gama na fruta, constatando sua eficiência na redução da contaminação microbiana no produto. Doses de 0,4 a 0,5 kGy foram eficientes na diminuição da contaminação de mesófilos e psicotróficos, sendo ainda satisfatórias no controle de fungos, bolores e leveduras. A mesma observação foi feita em estudo com mamão minimamente processado e irradiado (VIEITES et al., 2004).

Segundo Hurst (1995), é difícil medir o valor da sanitização por esta não ser refletida diretamente na parte econômica do processo (lucro e prejuízo). Esta é a razão pela qual muitos produtores não investem recursos necessários para garantir uma boa sanitização em sua planta de processamento. Tal fato torna-se ainda mais preocupante quando se considera que o aumento nas populações microbianas em minimamente processados impacta diretamente na vida útil destes produtos.

Para verificar o efeito da sanitização sobre atributos físico-químicos e microbiológicos de beterrabas minimamente processadas, Vitti e colaboradores (2004) submeteram amostras de beterraba a uma imersão em água clorada (200 mg $\mathrm{L}^{-1}$ de cloro ativo) por 6 minutos após o corte. Sob o aspecto microbiológico, os autores detectaram a redução da contaminação microbiana em relação ao tratamento controle, submetido apenas à pré-lavagem. Em nenhuma das amostras submetidas a pelo menos uma etapa de sanitização houve detecção de coliformes fecais.

Outro estudo, no qual foram avaliadas as condições higiênicas de 20 amostras de produtos hortícolas minimamente processados e congelados, constatou a ausência de coliformes totais e fecais de acordo com o método do Número Mais Provável, preconizado na Resolução $\mathrm{n}^{\circ} 12$, de janeiro de 2001 , publicada pelo Ministério da Saúde (FERREIRA et al., 2003). Ainda segundo os autores, os valores encontrados de coliformes totais sugerem um alimento adequadamente manipulado, bem como sanitização e conservação satisfatórias. Na análise não foi encontrado 
Salmonella, mas observou-se a presença de Staphylococcus spp em $15 \%$ das amostras. Os valores, de $10^{2}$ U.F.C/g, apesar de indicarem produtos em condição satisfatória, de acordo com os padrões exigidos pelo Ministério da Saúde, acusam contaminação na superfície de utensílios e equipamentos mal sanitizados e manipulação inadequada.

Oliveira e colaboradores (2005) analisaram amostras de alface minimamente processadas em Fortaleza, Ceará, sob o aspecto microbiológico. Constatou-se a presença de Salmonella sp, e contagens elevadas de coliformes a $35^{\circ} \mathrm{C}$, microorganismos aeróbios mesófilos e bolores e leveduras, indicando que, tanto a etapa de sanitização, como provavelmente as condições higiênico-sanitárias durante o processamento, foram insatisfatórias. É um fato ainda mais preocupante quando se considera que os minimamente processados geralmente são prontos para consumo imediato, o que expõe o consumidor a um risco ainda maior .

Enxágüe final: $O$ produto é imerso em água limpa, contendo de 3 a $5 \mathrm{mg} \mathrm{L}^{-1}$ de cloro livre, a fim de remover o excesso de cloro na solução aderida nos tecidos durante a sanitização. A água deve estar em temperatura entre $0^{\circ} \mathrm{C}$ e $5^{\circ} \mathrm{C}$ a fim de minimizar os efeitos do corte sobre o metabolismo do tecido vegetal (MORETTI e PUSCHMANN, 2006).

Centrifugação: É realizada para retirar o exsudato resultante do corte ou excesso de água de lavagem. Esta é outra etapa crítica dentro do fluxograma de processamento, pois deve evitar a disponibilidade de água livre no produto e o conseqüente desenvolvimento de microorganismos (LIMA et al., 2006). Para Lima e colaboradores (2006), a velocidade e o tempo de rotação nas centrífugas dependem do produto, devendo-se evitar a secagem excessiva e o aquecimento, para que não ocorra o murchamento ou enrugamento do produto. Moretti e Puschmann (2006) afirmam que o tempo ideal é aquele em que toda a água que foi adicionada ao produto por ocasião das imersões seja retirada, tomando-se o cuidado para não desidratá-lo. Os autores alertam ainda para casos de esbranquecimento superficial em cenoura e beterraba decorrentes da centrifugação em excesso. 
Embalagem: por serem mais perecíveis que seus similares intactos, as hortaliças e frutas minimamente processadas necessitam de embalagens que ajudem a minimizar ou retardar o processo de deterioração, estendendo ao máximo sua vida útil (MORETTI e PUSCHMANN, 2006). A embalagem pode ser realizada em sacos plásticos, em bandejas com cobertura plástica ou outros recipientes de plástico transparente (LIMA et al., 2006). Ainda segundo estes autores, a seleção da embalagem exige o conhecimento das características de cada produto, do estágio de maturação à colheita, cultivar, temperatura mínima de segurança para evitar injúria por excesso e falta de frio, permeabilidade menor ou maior a concentrações de gases envolvidos no processo respiratório $\left(\mathrm{O}_{2}\right.$ e $\left.\mathrm{CO}_{2}\right)$ e limiar de sensibilidade ao etileno no armazenamento.

Existem filmes com certas propriedades de permeabilidade a gases e vapor d'água, a uma dada temperatura, e sua seleção é fundamental para o estabelecimento da atmosfera adequada ao metabolismo do vegetal no interior da embalagem (MORETTI e PUSCHMANN, 2006). Desta forma, a embalagem pode ser realizada com vácuo parcial ou total com o uso de atmosfera modificada - AM (ativa ou passiva) ou atmosfera controlada (AC) (LIMA et al., 2006).

A redução do oxigênio, no interior da embalagem, inibe a proliferação da microbiota aeróbia presente, mas vai estimular o crescimento de microaerófilos e anaeróbios. Já o gás carbônico é o principal responsável pelo efeito bacteriostático observado em microorganismos que crescem em minimamente processados embalados sob atmosfera modificada (FARBER, 1991). Além disso, atmosferas com alta concentração de $\mathrm{CO}_{2}$ reduzem o pH celular e afetam o metabolismo microbiano (CANTWELL, 2000).

Para Lima e colaboradores (2006), ainda são necessárias mais pesquisas para se determinar as condições ótimas das embalagens sob atmosfera modificada para cada espécie ou mesmo para cada cultivar, a fim de aumentar a vida útil dos produtos. Segundo Pineli (2005), a produção de batatas minimamente processadas tem demandado pesquisas neste aspecto. 
Outro ponto relevante é a higiene e assepsia do recinto utilizado para realização da embalagem, o qual consiste na zona mais crítica da cadeia de processamento (LIMA et al., 2006), tendo em vista que o produto já sanitizado corre o risco de sofrer uma nova contaminação. Pinheiro e colaboradores (2005) constataram a presença de Salmonella sp em frutos minimamente processados comercializados em supermercados de Fortaleza. Um exemplo ocorreu em amostras de abacaxi, fruto de $\mathrm{pH}$ ácido que, aliado a uma estocagem sob refrigeração, é capaz de restringir o desenvolvimento do citado patógeno. A presença da bactéria no fruto indica, portanto, contaminação durante sua elaboração, principalmente após a etapa de sanitização, indicando, ainda, que as condições de armazenamento não foram eficientes.

Armazenamento: A fim de manter a qualidade e a segurança microbiológica do alimento minimamente processado, realiza-se seu armazenamento a uma temperatura entre $0^{\circ} \mathrm{C}$ e $5^{\circ} \mathrm{C}$.

A manutenção da cadeia de frio também é fundamental durante o transporte, preferencialmente em caminhões refrigerados ou em caixas de isopor previamente higienizadas e contendo gelo em escamas (MORETTI e PUSCHMANN, 2006).

O controle da temperatura é a técnica mais útil e importante disponível para minimizar os efeitos das injúrias provocadas pelo processamento mínimo de frutas e hortaliças, por reduzirem reações como aumento na respiração e na produção de etileno (BRECHT, 1995). Algumas bactérias, no entanto, crescem relativamente rápido mesmo sob refrigeração. É o caso dos gêneros Pseudomonas e Listeria (BRECHT, 1995; CANTWELL, 2000). Um estudo com cenoura e pimentão vermelho minimamente processados devidamente sanificados e acondicionados sob ar atmosférico, vácuo e atmosfera modificada, sendo, a seguir, armazenados a $1^{\circ} \mathrm{C} \pm$ $1^{\circ} \mathrm{C}$, demonstrou a presença de microorganismos psicrotróficos em todos os tratamentos (PILON et al., 2006).

A temperatura de armazenamento, além do seu efeito direto no crescimento bacteriano, também determina a taxa de respiração do produto, é responsável por 
alterações na atmosfera da embalagem e influencia o comportamento dos patógenos (DIXON e KELL, 1989 apud LANDGRAF e NUNES, 2006).

Embora não existam, na legislação brasileira vigente, padrões para bactérias psicrotróficas totais, no que condiz à quantidade de microorganismos presentes em um alimento, Caruso e Camargo (1984) afirmam que quantidades elevadas são completamente indesejáveis, considerando que o alimento pode estar estragado, com perda real ou potencial das qualidades organolépticas, comprometimento da aparência do alimento e presença de microorganismos patogênicos e/ou deterioradores.

Para Cantwell (2000), baixas temperaturas também são importantes para evitar reações de escurecimento e murchamento dos produtos minimamente processados, corroborando os consensos de segurança microbiana que ditam que os minimamente processados devem ser mantidos sempre o mais resfriado possível.

Análises microbiológicas de manga congelada e minimamente processada demonstraram uma eficiente inibição do crescimento microbiano sob baixas temperaturas, situação oposta ao verificado na manga minimamente processada conservada sob temperatura de $10^{\circ} \mathrm{C}$, cuja microbiota associada ao produto aumentou consideravelmente ao longo de 12 dias (PEREIRA et al., 2004).

Com o objetivo de relacionar a população microbiana inicial com o tempo de armazenamento e segurança do produto para o consumo, Rosa e colaboradores (2004) observaram a capacidade de bactérias, bolores e leveduras de se multiplicarem em baixas temperaturas em embalagens a vácuo, indicando sua habilidade potencial para causar deterioração em minimamente processados. Outro dado importante diz respeito à carga microbiana inicial. Nas amostras de hortaliças analisadas foram encontrados microorganismos mesófilos, psicrotróficos, coliformes fecais, bolores e leveduras em número elevado, não sendo, por isso, inativados pelas temperaturas de refrigeração empregadas.

A combinação de tratamentos pode ser bastante efetiva no aumento da vida útil destes produtos. Pilon e colaboradores (2006), em estudo sobre a cenoura 
embalada sob atmosfera modificada, ar atmosférico e vácuo, combinados a uma temperatura abaixo de $1^{\circ} \mathrm{C}$, observaram uma baixa contaminação bacteriana no alimento, o que enfatiza a importância da adoção de diferentes métodos de conservação para tornar os minimamente processados mais seguros.

Outro estudo, de Pereira e colaboradores (2003), analisou amostras de goiabas minimamente processadas acondicionadas sob atmosfera modificada em embalagens de polietileno tereftalato (PET), na temperatura de $5^{\circ} \mathrm{C}$ e osmoticamente desidratadas. Mais uma vez, concluiu-se que a combinação desses fatores resultou num produto mais estável à contaminação microbiológica e de melhor aceitação pelo consumidor, apresentando, ainda, características similares à fruta fresca.

Comercialização: Dependendo do mercado alvo, os produtos minimamente processados podem ser comercializados em embalagens de diversos tamanhos. Devem ficar expostos em balcões refrigerados, com temperatura ao redor de $5^{\circ} \mathrm{C}$, tendo em vista que seu aquecimento por algumas horas pode levar à deterioração e à perda total dentro de um dia. Para que não ocorra condensação de vapor d'água na superfície interna da embalagem, devem-se evitar variações de temperatura, como as que ocorrem em expositores refrigerados abertos, onde as temperaturas oscilam entre $10^{\circ} \mathrm{C}$ e $12^{\circ} \mathrm{C}$. Tal situação também antecipa a deterioração dos produtos, permitindo o aumento da população microbiana (MORETTI e PUSCHMANN, 2006).

Os resultados da pesquisa referente à qualidade microbiológica/sanitária de frutas e hortaliças minimamente processadas podem ser consultados na tabelaresumo a seguir: 
Tabela 1: Resultados da pesquisa referente à qualidade microbiológica de frutas e hortaliças minimamente processadas

\begin{tabular}{|c|c|c|c|}
\hline Referência & $\begin{array}{l}\text { Fruta ou } \\
\text { Hortaliça }\end{array}$ & $\begin{array}{l}\text { Microorganismos } \\
\text { encontrados }\end{array}$ & $\begin{array}{c}\text { Método de } \\
\text { conservação/sanitização }\end{array}$ \\
\hline 1 & Manga & $\begin{array}{l}\text { Mesófilos, psicrotróficos, } \\
\text { fungos, bolores e leveduras. }\end{array}$ & Radiação gama \\
\hline 2 & Beterraba & $\begin{array}{l}\text { Bactérias psicrotróficas, } \\
\text { coliformes totais, }\end{array}$ & Cloro \\
\hline 3 & $\begin{array}{l}\text { Hortícolas } \\
\text { diversos }\end{array}$ & Staphylococcus spp. & $*$ \\
\hline 4 & Alface & $\begin{array}{c}\text { Salmonella sp., coliformes a } \\
35^{\circ} \mathrm{C} \text {, mesófilos, bolores e } \\
\text { leveduras. }\end{array}$ & * \\
\hline 5 & Abacaxi & Salmonella sp. & * \\
\hline 6 & $\begin{array}{l}\text { Cenoura e } \\
\text { pimentão } \\
\text { vermelho }\end{array}$ & Psicrotróficos & $\begin{array}{c}\mathrm{AM}, \text { ar atmosférico ou } \\
\text { vácuo + temperatura }<1^{\circ} \mathrm{C}\end{array}$ \\
\hline 7 & $\begin{array}{c}\text { Manga } \\
\text { congelada } \\
\mathrm{e} \\
\text { refrigerada }\end{array}$ & $\begin{array}{l}\text { Coliformes totais e fecais, } \\
\text { mesófilos totais aeróbios e } \\
\text { fungos }\end{array}$ & $\begin{array}{c}\text { Baixas temperaturas: } \\
\text { * } 10^{\circ} \mathrm{C} \text { : manga refrigerada } \\
\text { * }-20^{\circ} \mathrm{C} \text { : manga congelada }\end{array}$ \\
\hline 8 & Goiaba & $\begin{array}{l}\text { Salmonella, coliformes, } \\
\text { bactérias lácticas }\end{array}$ & $\begin{array}{l}\text { AM, desidratação, } \\
\text { temperatura de } 5^{\circ} \mathrm{C} \\
\text { embalagem } \mathrm{PET}\end{array}$ \\
\hline
\end{tabular}

Fontes: (1) VIEITES et al., 2005; (2) VITTI et al., 2004; (3) FERREIRA et al., 2003; (4) OLIVEIRA et al., 2005; (5) PINHEIRO et al., 2005; (6) PILON et al., 2006; (7) PEREIRA et al., 2004; (8) PEREIRA et al., 2003.

* Estudos de análise microbiológica sem adoção de métodos de conservação.

\subsection{ASPECTOS MICROBIOLÓGICOS DE FRUTAS E HORTALIÇAS MINIMAMENTE PROCESSADAS}

Os maiores grupos de microorganismos envolvidos na deterioração e contaminação de produtos frescos são as bactérias e os fungos, apesar de vírus (como o da hepatite) e parasitas (ex.: Giardia) também serem preocupantes. No caso dos minimamente processados, o aumento nas superfícies danificadas pelo processamento e a disponibilidade de nutrientes celulares favorecem o crescimento microbiano. Some-se a isso o manuseio elevado durante a preparação destes produtos de conveniência, promovendo a contaminação por patógenos humanos, tais como a E. coli, Listeria, Yersinia e Salmonella (CANTWELL, 2000). 
Não há, no processamento mínimo, nenhum tipo de tratamento térmico que possa assegurar a inativação dos microorganismos presentes na matéria-prima e/ou aqueles adquiridos via manipulação, equipamentos, utensílios e ambiente. Dentro deste contexto, a adoção de procedimentos eficazes de higiene é imprescindível à produção desses alimentos (ANDRADE et al., 2004). De acordo com Suslow (2002), o consumo crescente de frutas e hortaliças frescas aumentou o risco de exposição a microorganismos patogênicos porque os processos de controle disponíveis para proteger o consumidor ainda são bastante limitados.

Somente nos Estados Unidos, nos últimos anos, aumentou-se a detecção de surtos de infecções alimentares relacionadas a produtos hortifrutícolas frescos domésticos e importados. Para se ter uma idéia da preocupação crescente dos países com a segurança alimentar referente a produtos frescos e minimamente processados, em 1997, divulgou-se nos Estados Unidos, por meio do então Presidente Bill Clinton, o plano Produce and Imported Foods Safety Initiative ("Iniciativa para Garantir a Segurança de Produtos Hortifrutícolas Importados e Domésticos"), como forma de minimizar os riscos causados por microorganismos patógenos a estes alimentos. Como resposta a esta iniciativa, foi lançado o "Guia para Minimização de Riscos Microbianos em Produtos Hortifrutícolas Frescos", uma forma de orientar o setor hortícola sobre boas práticas agrícolas e de administração referentes ao cultivo, colheita, lavagem, classificação, embalagem e transporte da maioria das frutas e vegetais vendidos a consumidores em forma não beneficiada ou sujeitos a processamento mínimo (crus) (FDA, 1998).

Durante a pré-colheita, os principais focos de microorganismos patogênicos e deteriorantes são o solo, as fezes, a água de irrigação, a água utilizada para aplicar fungicidas e inseticidas, poeira, insetos, compostagem inadequada do adubo, animais domésticos e selvagens e a manipulação humana (BRACKETT, 1999). Desta forma, o ambiente é o primeiro contaminante dos alimentos. O solo é rico em bactérias gram-positivas e fungos, que contaminam os alimentos de forma direta ou são transportados pelo vento ou por insetos. $O$ ar também atua, servindo como veículo destes microorganismos. Também há a chuva, que pode arrastar terra para produtos cultivados próximos ao solo, elevando sua carga microbiana, além de aumentar a umidade e favorecer o crescimento de fungos em até $72 \%$ (BRACKETT, 
1997). Jay (2005) destaca a importância da camada protetora de muitas frutas e vegetais e o pH que alguns possuem, com valores abaixo do $\mathrm{pH}$ de crescimento de muitos microorganismos, como fatores de forte influência na microbiologia destes produtos.

Dentre os microorganismos normalmente associados a plantas estão os patógenos vegetais dos gêneros Corynebacterium, Pseudomonas e Xanthomonas e os patógenos de origem fúngica, entre os quais estão diversos gêneros de mofos. São fungos e bactérias capazes de aderir à superfície da planta, de forma que não sejam facilmente lavados, além de prover suas necessidades nutricionais por meio das substâncias presentes nestes alimentos (JAY, 2005). No caso dos vegetais minimamente processados, destacam-se os deteriorantes Pseudomonas sp. e Erwinia sp. Segundo Andrade e colaboradores (2004), o gênero Pseudomonas é responsável, geralmente, por $50 \%$ a $90 \%$ da população microbiana de vegetais. Em termos de segurança microbiológica, merecem particular importância os patógenos psicrotróficos como L. monocytogenes, Aeromonas hydrophila e Yersinia enterocolitica e os mesófilos Salmonella, Escherichia coli 0157:H7 e Clostridium botulinum (LANDGRAF e NUNES, 2006).

As fontes de contaminação pós-colheita incluem fezes, manipulação humana, equipamentos de colheita, embalagens de transporte, animais, insetos, poeira, água de lavagem, gelo, veículos de transporte e equipamentos envolvidos no processo (BRACKETT, 1999). São situações que também podem estar presentes como fonte de contaminação durante a colheita (LANDGRAF e NUNES, 2006).

Os utensílios são outra fonte primária de microorganismos encontrados em alimentos. Pode-se esperar que alguns ou todos os organismos presentes na superfície desses objetos contaminem as superfícies de contato do alimento (JAY, 2005). Brackett (1997) afirma que, além disso, determinados recipientes com superfícies desiguais ou salientes podem rasgar hortaliças e cascas de frutas. Os danos provocados levam à liberação do suco nutritivo, que permite o crescimento microbiano nos equipamentos e nos próprios alimentos. Segundo o autor, mesmo microorganismos não-deteriorantes em outras condições podem ocasionar a 
degradação do produto após a perda da proteção natural que as cascas representam.

Beuchat (2002) afirma que a infiltração de patógenos no interior dos tecidos dos vegetais depende da temperatura, tempo e pressão. A temperatura, no entanto, é, provavelmente, o fator que mais afeta o crescimento de microorganismos (BRACKETT, 1997; CANTWELL, 2000). Como as frutas e hortaliças são cultivadas e colhidas em temperatura ambiente, nos países de clima quente, como o Brasil, é comum a predominância de bactérias mesofílicas (PORTE e MAIA, 2001). Segundo estes autores, o tratamento de refrigeração que ocorre na maioria dos alimentos minimamente processados tem contribuído, entretanto, para a predominância de psicrotróficos.

Microbiologicamente, elevadas concentrações de $\mathrm{CO}_{2}$ e/ou reduzidas de $\mathrm{O}_{2}$ podem favorecer ou selecionar certas classes de microorganismos. A baixa concentração de $\mathrm{O}_{2}$ e elevada concentração de $\mathrm{CO}_{2}$ favorecem o crescimento de microorganismos microaerófilos, como Listeria, bactérias láticas e outras bactérias gram-positivas em relação às gram-negativas (LANDGRAF e NUNES, 2006). Ainda, a atmosfera no interior da embalagem afeta também o metabolismo do alimento, como afirmam Porte e Maia (2001).

Na tabela abaixo, encontram-se exemplos de microorganismos patogênicos encontrados em frutas e vegetais.

Tabela 2: Principais microorganismos patogênicos encontrados em frutas e vegetais

\begin{tabular}{|c|c|c|c|}
\hline $\begin{array}{c}\text { Microorganismo } \\
\text { patogênico }\end{array}$ & Tipo de organismo & $\begin{array}{c}\text { Maiores } \\
\text { transmissores }\end{array}$ & Fonte primária \\
\hline Salmonella & Bactéria & $\begin{array}{c}\text { Animais de produção } \\
\text { Animais domésticos } \\
\text { Animais selvagens } \\
\text { Contaminação } \\
\text { cruzada por carne, } \\
\text { frango, ovos. }\end{array}$ & $\begin{array}{c}\text { Fezes } \\
\text { Carcaça } \\
\text { Solo }\end{array}$ \\
\hline Campylobacter & Bactéria & $\begin{array}{c}\text { Contaminação } \\
\text { cruzada por carne, } \\
\text { frango, ovos. }\end{array}$ & Carcaças \\
\hline
\end{tabular}




\begin{tabular}{|c|c|c|c|}
\hline $\begin{array}{c}\text { Escherichia coli } \\
\text { O157:H7 }\end{array}$ & $\begin{array}{c}\text { Animais de produção } \\
\text { Animais domésticos } \\
\text { Animais selvagens } \\
\text { Humanos } \\
\text { Contaminação } \\
\text { cruzada por carne, } \\
\text { frango. }\end{array}$ & $\begin{array}{c}\text { Fezes } \\
\text { Água } \\
\text { Solo }\end{array}$ \\
\hline Cryptosporidium & Protozoário & $\begin{array}{c}\text { Animais de produção } \\
\text { Animais domésticos } \\
\text { Animais selvagens } \\
\text { Humanos }\end{array}$ & $\begin{array}{c}\text { Fezes } \\
\text { Água }\end{array}$ \\
\hline Toxoplasma & Protozoário & $\begin{array}{c}\text { Animais de produção } \\
\text { Gatos }\end{array}$ & Fezes \\
\hline Cyclospora & Parasita & Humanos & $\begin{array}{c}\text { Fezes } \\
\text { Água }\end{array}$ \\
\hline
\end{tabular}

Adaptado de Suslow (2002).

As frutas e hortaliças apresentam características químicas diferentes, que refletem na composição da microflora presente (PORTE e MAIA, 2001) em cada um destes produtos (Tabela 2). Por apresentarem elevada quantidade de água e de nutrientes e um pH neutro, as hortaliças apresentam uma microflora predominante em bactérias (BRACKETT, 1997). Já as frutas apresentam maiores quantidades de açúcar e pH mais ácidos (4,6 ou menos), o que desfavorece o crescimento de bactérias que não sejam as láticas. Nestes alimentos, portanto, prevalecem os fungos (PORTE e MAIA, 2001).

Tabela 3: Microorganismos mais comuns em hortaliças e frutas

\begin{tabular}{|c|c|c|c|}
\hline Alimentos & Bactérias & Leveduras & Bolores \\
\hline Hortaliças & $\begin{array}{l}\frac{\text { Gram-negativas }}{\text { Pseudomonas sp. }} \\
\quad \text { Erwinia sp. } \\
\text { Enterobacter sp. } \\
\frac{\text { Gram-positivas }}{\text { Bacillus } s p .}\end{array}$ & $\begin{array}{c}\text { Não fermentativas } \\
\text { Cryptococcus } s p . \\
\text { Rhodotorula } s p . \\
\frac{\text { Fermentativas }}{\text { Cândida } s p .} \\
\text { Kloeckera } s p .\end{array}$ & $\begin{array}{l}\text { Aureobasidium sp. } \\
\text { Fusarium sp. } \\
\text { Alternaria sp. } \\
\text { Epicoccum } s p . \\
\text { Mucor } s p . \\
\text { Chaetomium } s p . \\
\text { Rhisopus } s p . \\
\text { Phoma sp. }\end{array}$ \\
\hline Frutas & ---- & $\begin{array}{c}\text { Saccharomyces sp. } \\
\text { Hanseniaspora sp. } \\
\text { Pichia sp. } \\
\text { Kloeckera sp. } \\
\text { Candida sp. } \\
\text { Rodhotorula sp. }\end{array}$ & $\begin{array}{l}\text { Aspergillus sp. } \\
\text { Penicillium sp. } \\
\text { Mucor } s p . \\
\text { Alternaria } s p . \\
\text { Cladosporium } s p . \\
\text { Botrytis } s p .\end{array}$ \\
\hline
\end{tabular}

Fonte: BRACKETT, 1997. 
Alguns dos microorganismos descritos nas tabelas acima, por serem importantes patógenos, terão suas características apresentadas a seguir, como forma de enfatizar a sua importância na segurança alimentar.

Bacillus: são bastonetes Gram-positivos, formadores de esporos e aeróbios. É um gênero que contém apenas dois patógenos: $B$. anthracis (agente causal da doença 'Antrax') e $B$. cereus, a qual possui algumas linhagens que causam gastrenterite. Segundo Jay (2005), essa bactéria produz uma grande variedade de toxinas e enzimas extracelulares causadoras das síndromes diarréica (náuseas, dores abdominais intermitentes, tenesmo e fezes aquosas, geralmente sem febre) e emética (vômitos intensos), esta última mais grave e aguda que a primeira. Surtos já foram registrados na Grã-Bretanha, no Canadá, na Austrália, na Holanda, na Finlândia, no Japão e nos Estados Unidos, envolvendo, dentre outros alimentos, brotos vegetais.

E. coli: Esta bactéria é o indicador de contaminação fecal (coliforme fecal, também chamado de termorresistente) e tem a capacidade de se multiplicar em resíduos de alimentos e nas superfícies dos equipamentos e utensílios. O quadro clínico inclui diarréia, vômito, febre, cólica, mal estar e calafrios (SILVA JR., 2002).

E. coli 0157:H7: Causa uma doença chamada colite hemorrágica, caracterizada por fortes cólicas abdominais, diarréia inicialmente aquosa e depois com sangue. Os surtos estão mais relacionados ao consumo de carne mal cozida ou crua e leite cru (SILVA JR., 2002). No entanto, como citado na Tabela 1, estes alimentos podem servir de fonte microbiológica para contaminação de frutas e vegetais a serem servidos crus.

Salmonella sp.: Esta bactéria, bastante agressiva, leva a um quadro clínico de diarréia, mal estar e cólicas, com ou sem febre (SILVA JR., 2002) e está entre os mais importantes Gram-negativos causadores de gastrenterites (JAY, 2005). De acordo com Silva Jr. (2002), das 7.907 salmonelas isoladas pelo Centro de Controle de Doenças dos EUA durante o ano de 1996, 70\% foram provenientes de alimentos crus e processados. Um dado importante diz respeito ao aparecimento de patógenos em brotos de alfafa, assunto de grande interesse e cujos métodos para prevenção e 
tratamento têm sido testados. É uma forma de contaminação secundária, já que a presença deste microorganismo em carnes, ovos e mesmo no ar torna sua presença inevitável em certos alimentos.

A descrição das bactérias acima mostra sua importância no contexto de saúde pública, no âmbito dos produtos minimamente processados, comprovando que a contaminação destes, de forma direta ou secundária, é capaz de causar males diversos à saúde da população. Tal situação demanda esforços por parte do governo, produtores e demais áreas envolvidas no processamento mínimo com o intuito de desenvolver medidas capazes de evitar ou reduzir casos de surtos. A higiene, nesses casos, é o carro-chefe no combate à contaminação. 


\section{CONCLUSÃO}

Os alimentos minimamente processados vêm obtendo, de forma considerável, uma grande participação no mercado de produtos frescos e prontos para o consumo. Um grande entrave para um maior crescimento deste setor de mercado tem sido a curta vida útil destes produtos, provocada, sobretudo, por desordens fisiológicas, bioquímicas e microbiológicas. Estas últimas são de grande preocupação para a saúde pública, principalmente quando são considerados os gastos decorrentes do atendimento a pacientes vitimados por doenças veiculadas por alimentos, uma verba que poderia ser investida em outros setores, como o desenvolvimento de novas tecnologias de conservação destes produtos.

É imprescindível, desta forma, que a indústria de alimentos minimamente processados controle a higiene da matéria-prima, baseada em fundamentos tecnológicos comprovadamente eficientes, tais como o controle da temperatura de refrigeração e o emprego de técnicas combinadas de conservação (atmosfera modificada, atmosfera controlada, radiação, sanitização com cloro, dentre outros). É uma forma de garantir a disponibilização destes produtos ao consumidor de forma segura, principalmente do ponto de vista microbiológico/sanitário. 


\section{REFERÊNCIAS BIBLIOGRÁFICAS}

ABERC. Associação Brasileira de Empresas de Refeições Coletivas. Disponível em: <http://www.aberc.com.br>. Acesso em: 01 de Agosto de 2006.

AGUILA, J. S. del; SASAKI, F. F.; HEIFFIG, L. S.; ONGARELLI, M. G.; GALLO; C. R.; JACOMINO, A. P.; KLUGE, R. A. Determinação da microflora em rabanetes minimamente processados. Horticultura Brasileira, v. 24, n. 1, p. 75-78, jan.-mar. 2006.

ALVES, R. E.; SOUZA FILHO; M. de S. M. de; BASTOS, M. do S. R.; FILGUEIRAS, H. A. C.; BORGES, M. de F. Pesquisa em Processamento Mínimo de Frutas no Brasil. In: II ENCONTRO NACIONAL SOBRE PROCESSAMENTO MÍNIMO DE FRUTAS E HORTALIÇAS. Palestras, Viçosa: UFV, 2000. p. 110.

ANDRADE, N. J.; ANTUNES, M. A.; BASTOS, M. S. R. Higiene nas indústrias de alimentos minimamente processados. In: III ENCONTRO NACIONAL SOBRE PROCESSAMENTO MÍNIMO DE FRUTAS E HORTALIÇAS. Palestras, Viçosa: UFV, 2004. p.40.

BERBARI, S. A. G.; PASCHOALINO, J. E.; SILVEIRA, N. F. A. Efeito do cloro na água de lavagem para desinfecção de alface minimamente processada. Ciência Tecnol. Aliment., Campinas, v. 21, n. 2, p. 197-201, 2001.

BEUCHAT, L. R. Ecological factors influencing survival and growth of human pathogens on raw fruits and vegetables. Microbes Inf., v. 4, 2002.

BRACKETT, R. E. Alteraciones microbiológicas y microorganismos patógenos de frutas y hortalizas refrigeradas minimamente procesadas. In: WILEY, R.C. Frutas y hortalizas minimamente procesadas y refrigeradas. Zaragoza: Acribia, 1997.

BRACKETT, R. E. Incidence, contributing factors, and control of bacterial pathogens in produce. Postharvest Biol. Technol., v. 15, p. 305-311, 1999.

BRECHT, J. K. Physiology of Lightly Processed Fruits and Vegetables. HortScience, v. 30, n. 1, p. 18-22, 1995.

BURNS, J. K. Lightly Processed Fruits and Vegetables: Introduction to the Colloquium. HortScience, v. 30, n. 1, p. 14, 1995.

CANTWELL, Marita. 2002. Postharvest handling systems: minimally processed fruits and vegetables. University of California, Vegetable Research \& Information 
Center. Disponível em: <http://vric.ucdavis.edu/selectnewtopic.minproc.htm>. Acesso em: 20 de junho de 2006.

CANTWELL, Marita. Preparation and quality of fresh-cut produce. In: II ENCONTRO NACIONAL SOBRE PROCESSAMENTO MÍNIMO DE FRUTAS E HORTALIÇAS. Palestras, Viçosa: UFV, 2000. p. 110.

CARUSO, J. G. B.; CAMARGO, R. Microbiologia de alimentos. In: CAMARGO, R. (Ed.). Tecnologia dos produtos agropecuários: $\mathbf{n}$ alimentos. São Paulo: Nobel, 1984. p. 35-49.

CHITARRA, M. I. F. Processamento mínimo de frutas e hortaliças. Tecnologia e Treinamento Agropecuário, v.2, p.7, 1999.

CHITARRA, M. I. F; CHITARRA, A. B. Pós-colheita de frutos e hortaliças: Fisiologia e Manuseio. Lavras: ESAL/FAEPE, 1990, 320 p.

DIXON, N.M.; KELL, D.B. The inhibition by $\mathrm{CO}_{2}$ of the growth and metabolism of microorganisms: a review. J. Appl. Bacteriol., v. 67, p. 109-136, 1989.

DURIGAN, J. F.; SARGENT, S. A. Uso do melão Cantaloupe na produção de produtos minimamente processados. Alimentos e Nutrição, São Paulo, v. 10, p. 6977, 1999.

FANTUZZI, E.; PUSCHMANN, R.; VANETTI, M. C. D. Microbiota contaminante em repolho minimamente processado. Ciência e Tecnologia de Alimentos, Campinas, v. 24, n. 2, p. 207-211, abr.-jun. 2004.

FARBER, J. Microbiological issues surrounding the safety of fresh cut produce. $10^{\text {th }}$, World Congress of Food Science and Technology. Abstract Book, Sydney, 1991.

FDA. U. S. Food And Drug Administration. Guia para Minimização de Riscos Microbianos, 1998. Disponível em: <http://www.fda.gov>. Acesso em: 15 de dezembro de 2006.

FERREIRA, M. G. A. B.; BAYMA, A. B.; MARTINS, A. G. L. A.; JÚNIOR, A. V. G. MARINHO, S. C. Aspectos higiênico-sanitários de legumes e verduras minimamente processados e congelados. Higiene Alimentar, v. 17, n. 106, 2003.

FURLANETO, L.; SANTINI, M. S.; VELASCO, F. A. S. Análise microbiológica de vegetais e hortaliças minimamente processados. Higiene Alimentar, v. 19, n. 131, 2005. 
HURST, W. C. Sanitation of Lightly Processed Fruits and Vegetables. HortScience, vol. 30, n. 1, 1995.

IFPA. International Fresh-Cut Produce Association. Fresh-cut produce handling guidelines. 3. ed. Produce Marketing, 1999, $39 \mathrm{p}$.

JAY, J. M. Microbiologia de Alimentos. 6 ed. Porto Alegre: Artmed, 2005.

KLUGE, R. A.; VITTI, M. C. D.; JACOMINO, A. P. Beterraba minimamente processada: praticidade e economia de tempo. Horticultura Brasileira, Brasília, v.21, n. 4, p. 1, out.-dez. 2003.

KLUGE, R. A.; VITTI, M. C. D. Processamento Mínimo de Beterraba. In: III ENCONTRO NACIONAL SOBRE PROCESSAMENTO MÍNIMO DE FRUTAS E HORTALIÇAS. Palestras, Universidade Federal de Viçosa. Viçosa, 2004, p. 83.

LANDGRAF, M.; NUNES, T. P. Microbiologia em frutas e hortaliças minimamente processadas. IV ENCONTRO NACIONAL SOBRE PROCESSAMENTO MÍNIMO DE FRUTAS E HORTALIÇAS. Palestras, Universidade de São Paulo. São Paulo, 2006, p. 60.

LIMA, L. C. de O.; SIQUEIRA, H. H.; BOTELHO, M. Fluxo do Processamento Mínimo. IV ENCONTRO NACIONAL SOBRE PROCESSAMENTO MÍNIMO DE FRUTAS E HORTALIÇAS. Palestras, Universidade de São Paulo. São Paulo, 2006, p. 240.

LUENGO, R. de F. A.; CALBO, A. G. Armazenamento de hortaliças. Brasília: Embrapa Hortaliças, 2001, $242 \mathrm{p}$.

MATTIUZ, B. H. Processamento Mínimo de Frutas Tropicais: Goiaba. In: III ENCONTRO NACIONAL SOBRE PROCESSAMENTO MÍNIMO DE FRUTAS E HORTALIÇAS. Palestras, Universidade Federal de Viçosa. Viçosa, 2004, p. 96.

MORETTI, C. L. Processamento mínimo de hortaliças: alternativa viável para a redução de perdas pós-colheita e agregação de valor ao agronegócio brasileiro. Horticultura Brasileira, Brasília, v. 17, n. 2 p. 1, julho 1999.

MORETTI, C. L. Processamento mínimo de hortaliças: Tendências e desafios. Horticultura Brasileira, Brasília, v. 19, n. 2, p. 172 Suplemento, Palestras, julho 2001.

MORETTI, C. L. Processo de Produção e Controle de Qualidade. In: EMBRAPA. Iniciando um Pequeno Grande Negócio Agroindustrial: Hortaliças Minimamente Processadas. Brasília: Embrapa Informação Tecnológica, 2003a, 133p. 
MORETTI, C. L. O Segredo do Sucesso é a Qualidade. In: EMBRAPA. Iniciando um Pequeno Grande Negócio Agroindustrial: Hortaliças Minimamente Processadas. Brasília: Embrapa Informação Tecnológica, 2003b, 133p.

MORETTI, C. L.; ARAÚJO, A. L.; MATTOS, L. M. Evaluation of different oxygen, carbon dioxide and nitrogen combinations employed to extend shelf life of fresh-cut collard greens. Horticultura Brasileira, v. 21, n. 4, p. 676-680, out.-dez. 2003.

MORETTI, C. L.; SARGENT, S. A. Alteração de sabor e aroma em tomates causada por impacto. Scientia Agrícola, v. 57, n. 3, p. 385-388, 2000.

MORETTI, C. L.; PUSCHMANN, R. Processamento Mínimo de Hortaliças. In: IV ENCONTRO NACIONAL SOBRE PROCESSAMENTO MÍNIMO DE FRUTAS E HORTALIÇAS. Palestras, Universidade de São Paulo. São Paulo, 2006, p. 234.

NASCIMENTO, E. F. Produção de hortaliças minimamente processadas no Distrito Federal. Horticultura Brasileira, Brasília, v. 19, p. 174 Suplemento, Palestras, julho 2001.

OLIVEIRA, A. M. C.; PINTO, G. A. S.; BRUNO, L. M.; AZEVEDO, E. H. F. Avaliação da qualidade higiênico-sanitária de alface minimamente processada, comercializada em Fortaleza, CE. Higiene Alimentar, v. 19, n. 135, 2005.

PEREIRA, K. S.; PEREIRA, J. L.; MIYA, N. T. N. Análises microbiológicas de manga, cultivar Palmer, congelada e minimamente processada. Higiene Alimentar, v. 18, n. 119, p. 47-50, abr. 2004.

PEREIRA, L. M.; RODRIGUES, A. C. C.; SARANTÓPOULOS, C. I. G. L.; JUNQUEIRA, V. C. A.; CARDELLO, H. M. A. B.; HUBINGER, M. D. Vida de prateleira de goiabas minimamente processadas acondicionadas em embalagens sob atmosfera modificada. Ciência Tecnol. Aliment., Campinas, v. 23, n. 3, p. 427433, 2003.

PILON, L.; OETTERER, M.; GALLO, C. R.; SPOTO, M. H. F. Shelf-life of minimally processed carrot and green pepper. Ciência e Tecnologia de Alimentos, Campinas, v. 26, n. 1, p. 150-158, jan.-mar. 2006.

PINELI, L. L. O.; ARAÚJO, W. M. C. Produção, qualidade e segurança sanitária de vegetais minimamente processados. Higiene Alimentar, v. 20, n. 141, p. 55-60, maio-jun. 2006. 
PINELI, L. de L. de O. Caracterização física, química, sensorial e nutricional de batatas minimamente processadas. 2005. 219 p. Dissertação (Mestrado em Nutrição Humana) - Universidade de Brasília, Brasília, 2005.

PINHEIRO, N. M. S.; FIGUEIREDO, E. A. T.; FIGUEIREDO, R. W.; MAIA, G. A.; SOUZA, P. H. M. Avaliação da qualidade microbiológica de frutos minimamente processados comercializados em supermercados de fortaleza. Rev. Bras. Frutic., Jaboticabal - SP, v. 27, n. 1, p. 153-156, 2005.

POPKIN, Barry M. The nutrition transition and obesity in the developing world. Journal of Nutrition, 131:871S-873S, 2001.

PORTE, A.; MAIA, L. H. Alterações fisiológicas, bioquímicas e microbiológicas de alimentos minimamente processados. B. CEPPA, Curitiba, v. 19, n.1, 2001.

ROSA, O. O.; CARVALHO, E. P.; DIONÍZIO, F. L.; RIBEIRO, A. C.; BEERLI, K. M. Indicadores de contaminação ambiental e de condições higiênicas insatisfatórias de processamento, em hortaliças minimamente processadas. Higiene Alimentar, v. 18, n. 122, 2004.

SAABOR, A. A importância dos pré-processados. Frutifatos, v. 1; n. 1, p. 16-18, 1999. Disponível em: <http://www.integracao.gov.br/infraestruturahidrica/publicacoes /frutifatos.asp>. Acesso em: 01 de Agosto de 2006.

SAABOR, A. Comercialização de hortaliças sob o enfoque do mercado varejista. Horticultura Brasileira, Brasília, v. 19, p. 180 Suplemento, Palestras, julho 2001.

SHEWFELT, R. L. Postharvest treatment for extending the shelf life of fruits and vegetables. Food Technology, v. 40, n. 5, may 1986.

SCHLIMME, D. V. Marketing Lightly Processed Fruits and Vegetables. HortScience, v. 30, n. 1, p. 15, 1995.

SILVA, E. O.; CARNELOSSI, M. O. G.; SOARES, N. F. F.; VANETTI, M. C. D.; PUSCHMANN, R. Como montar uma agroindústria de processamento mínimo de vegetais, Universidade Federal de Viçosa, Viçosa 2002, 70 p.

SILVA JR., E. A. Manual de Controle Higiênico-Sanitário em Alimentos. 5. ed. São Paulo: Varela, 2002. 
SKURA, B. J.; POWRIE, W. D. Modified atmosphere packing of fruits and vegetables. In: Vegetable processing. New York: VCH Publishers, 1995. 279 p.

SOUZA, R. A. M. de. Mercado para produtos minimamente processados. Informações Econômicas, São Paulo, v. 31, n. 3, p. 7-18, 2001.

SOUZA, R. A. M. de; SILVA, R. de O. P. e; MANDELLI, C. S.; TASCO, A. M. P. Comercialização Hortícola: análise de alguns setores do mercado varejista de São Paulo. Informações Econômicas, São Paulo, v. 28, n. 10, p. 7-23, 1998.

SUSLOW, T. Microbial Food Safety Is Your Resposibility! University of California, Vegetable Research Information Center, 2002. 7 p. Disponível em: $<$ http://vric.ucdavis.edu/veginfo/foodsafety/foodsafety.PDF>.Acesso em: 20 de janeiro de 2007.

SUSLOW, T. Postharvest Chlorination: Basic properties and key points for effective disinfection. University of California, Division of Agriculture and Natural Resources. 1997. 8p. Disponível em: <http://danrcs.ucdavis.edu.>. Acesso em: 20 de janeiro de 2007.

VANETTI, M. C. D. Controle Microbiológico e Higiene no Processamento Mínimo. In: II ENCONTRO NACIONAL SOBRE PROCESSAMENTO MÍNIMO DE FRUTAS E HORTALIÇAS. Palestras, Universidade Federal de Viçosa. Viçosa, 2000, p. 45.

VIEITES, R. L.; EVANGELISTA, R. M.; CAMPOS, A. J.; MOREIRA, G. C. Avaliação da contaminação microbiana do mamão minimamente processado e irradiado. Higiene Alimentar, v. 18, n. 118, 2004.

VIEITES, R. L.; EVANGELISTA, R. M.; CAMPOS, A. J.; MOREIRA, G. C. Efeito da radiação gama na sanitização da manga minimamente processada. Higiene Alimentar, v. 18, n. 135, 2005.

VITTI, M. C. D. Aspectos fisiológicos, bioquímicos e microbiológicos em beterrabas minimamente processadas. 2003. 116 p. Dissertação (Mestrado em Fisiologia e Bioquímica de Plantas) - Escola Superior de Agricultura Luiz de Queiroz/USP, Piracicaba, 2003.

VITTI, M. C. D.; KLUGE, R. A.; JACOMINO, A. P. Comportamento da beterraba minimamente processada em diferentes espessuras de corte. Horticultura Brasileira, Brasília, v. 21, n. 4, p. 623-626, out.-dez. 2003. 
VITTI, M. C. D.; KLUGE, R. A.; GALLO, C.R; MORETTI, C.L.; JACOMINO, A. P. Efeito do momento de sanitização sobre atributos físico-químicos e microbiológicos de beterrabas minimamente processadas. Horticultura Brasileira, Brasília, v. 22, n. 4, p. 718-721, out-dez 2004.

ZAGORY, D. Sanitation Concerns In The Fresh-cut Fruit and Vegetable Industry. Washington State University, 16th Annual Postharvest Conference \& Trade Show, March 14 \& 15, 2000, Yakima Convention Center. Disponível em: < http://www.davisfreshtech.com/articles_freshcut.pdf >. Acesso em: 20 de janeiro de 2007.

ZAGORY, D. Wash Water Sanitation: How do I Compare Different Systems? 2003. Disponível em: <http://www.davisfreshtech.com/articles_washwater.pdf>. Acesso em: 20 de janeiro de 2007. 